\title{
Short communication: Bacterial counts in recycled manure solids bedding replaced daily or deep packed in freestalls
}

\author{
D. E. Sorter, H. J. Kester, and J. S. Hogan ${ }^{1}$ \\ The Ohio State University, Ohio Agricultural Research and Development Center, Wooster 44691
}

\begin{abstract}
An experiment was conducted to compare bacterial counts of mastitis pathogens in deep-packed manure solids bedding with those in manure solids bedding replaced daily from mattresses. Eighteen Holstein cows were housed in 1 pen with 18 stalls. One row of 9 stalls was equipped with mattresses topped with bedding. The back one-third of these stalls toward the alleyway was covered in $25 \mathrm{~mm}$ of recycled manure solids, which was removed daily for the next $6 \mathrm{~d}$ and replaced with bedding from the brisket board and lunge space areas of stalls. The second row of 9 stalls was bedded for $3 \mathrm{wk}$ with 100 to $150 \mathrm{~mm}$ of deep-pack recycled manure bedding from which only fecal matter was removed daily. After $3 \mathrm{wk}$, bedding treatments were changed between rows in a switchback design. Mean total gram-negative bacterial counts did not differ between treatments throughout the experiment. Coliform and Klebsiella spp. bacterial counts were lower in daily replaced bedding compared with deep pack across the experiment and on each of d 0, 1, 2, and 6. Streptococcal counts were reduced in daily replacement stalls compared with deep-pack stalls on d 0 and greater in daily replacement stalls compared with deep-pack stalls on d 1, 2, and 6 . Daily replacement of recycled manure bedding from the back one-third of the stalls appeared to be an effective approach to reducing exposure to coliforms, specifically Klebsiella, but not streptococci. However, bacterial counts in bedding from both treatments were elevated throughout the trial and resulted in considerable risk for exposure to teats and development of intramammary infections.
\end{abstract}

Key words: recycled manure solids, bacterial counts, bedding

\section{Short Communication}

Increased cost and decreased availability of common bedding materials have led to a growing interest in using

Received December 10, 2013.

Accepted February 5, 2014.

${ }^{1}$ Corresponding author: hogan.4@osu.edu recycled manure solids as bedding (Husfeldt et al., 2012). Two common ways of using recycled manure bedding are in the forms of deep-bedded packs or surface application on top of mattresses (Husfeldt and Endres, 2012). The use of deep-bedded manure solids in freestalls was associated with reduced lameness and hock abrasions compared with use of recycled manure solids as bedding on mattresses (Husfeldt and Endres, 2012). In addition to cow comfort and welfare, the choice of bedding for freestalls has an effect on mammary health. Bacterial populations in bedding were positively correlated with teat skin bacterial populations (Zdanowicz et al., 2004) and rates of clinical mastitis in lactating cows (Hogan et al., 1989). Use of manure solids as bedding has a large potential effect on pathogen load in stalls because it provides pathogens with a nutrient-rich environment (Gooch et al., 2006). In an observational study, the incidence of clinical mastitis was not different between bedding management practices, although deep-bedded stalls had reduced streptococcal counts compared with bedding on mattresses (Husfeldt et al., 2012).

The ability of bacteria to multiply in bedding can be influenced by physical, biochemical, or nutritional properties of the material chosen and the management of bedding in stalls (Godden et al., 2008). Management strategies to reduce mastitis pathogen populations in organic bedding have been minimally successful in controlled trials (reviewed by Hogan and Smith, 2012). An exception was the report by Bramley (1985) of daily replacement of sawdust bedding from the back one-third of concrete stalls that reduced bacterial contamination of bedding and was related to a reduced incidence of coliform mastitis. The purpose of the current controlled trial was to compare bacterial counts of mastitis pathogens in deep-packed manure solids bedding with those in manure solids bedding replaced daily from mattresses.

An experiment was conducted at the Ohio Agricultural Research and Development Center Krauss Dairy Center (Wooster, OH) during May and June 2013. Eighteen lactating Holsteins cows were housed in 1 pen with unlimited access to 18 freestalls. Each stall was a $203 \times 127 \mathrm{~cm}$ concrete base with rubber-filled, vinyl-surfaced, cushioned mats. The pen consisted of 2 rows of freestalls separated by a 3.05-m alley. Fans 
(1.2-m diagonal propeller length) were every $6.1 \mathrm{~m}$ and suspended $2.7 \mathrm{~m}$ above both rows of stalls. Stalls were separated from feed and water by a $2.13-\mathrm{m}$-wide alley and a solid board partition measuring $1.22 \mathrm{~m}$ in height. Stalls were separated from the exterior side-open walls of the barn by a $1.22-\mathrm{m}$ tall board partition and a 1.5$\mathrm{m}$ cow transport alley. The pen and feed alleys were cleaned 8 times per day during the study by manual control of a mechanical scraper. Recycled manure was recovered solids (FAN PSS; Fan Separator Inc., Michigan City, IN) from the trial herd. Recycled manure solids were stored in a covered shed and were used as bedding within $3 \mathrm{~d}$ after separation.

One row of 9 stalls was covered with vinyl-surfaced mattresses. All bedding was removed once per week on Mondays at $0700 \mathrm{~h}$; approximately $30 \mathrm{~kg}$ of fresh recycled manure bedding was added to the brisket and lunge space areas of stalls and the back one-third of stalls was covered in 25-mm recycled manure solids. For the next $6 \mathrm{~d}$, all bedding was completely removed daily from the back one-third of mattresses and bedding from the brisket area and lunge space of stalls was pulled to the back one-third of stalls to maintain a bedding depth of $25 \mathrm{~mm}$. The remaining row of 9 stalls was bedded with 100 to $150 \mathrm{~mm}$ of deep-packed, recycled manure solids. Minimal bedding was added to deep-pack stalls only to replenish bedding removed due to fecal contamination. Stalls received the same treatment for 3 consecutive weeks. After 3 wk with a bedding treatment, bedding treatments were changed between rows. The trial was $6 \mathrm{wk}$ long so that stalls were exposed to both bedding treatments in a switchback design to account for differences among stalls. Stalls directly across the walk alley between rows were paired for statistical analysis. The Ohio Agricultural Research and Development Center climatological station, located $1.9 \mathrm{~km}$ from the research dairy, reported that the average daily high temperature was $27.2^{\circ} \mathrm{C}$ (range: 23.8 to $31.1^{\circ} \mathrm{C}$ ) and the average daily low temperature as $15.5^{\circ} \mathrm{C}$ (range 12.7 to $16.1^{\circ} \mathrm{C}$ ) during the experiment.

Bedding samples in 4 stalls per treatment group were collected from the surface $25 \mathrm{~mm}$ of bedding in the back one-third of stalls. Samples were collected from both experimental groups immediately after fresh bedding was added to daily replacement stalls (d 0) and immediately before daily removal of bedding on $\mathrm{d} 1,2$, and 6 of each week. The samples were tested for DM composition and bacteriological counts. Two grams of sample were placed in a gravity-convection oven at $100^{\circ} \mathrm{C}$ for $24 \mathrm{~h}$ and the DM content was determined. Ten grams of bedding was added to $90 \mathrm{~mL}$ of sterile saline and mixed for $30 \mathrm{~s}$ in a stomacher (Stomacher Lab Blender 400; Tekmar Co., Cincinnati, OH). The solution was diluted in $225 \mathrm{~mL}$ of sterile saline and plated on the surface of MacConkey agar (Becton Dickinson Microbiology Systems, Cockeysville, MD), MacConkey-inositol-carbenicillin agar with inositol (10 mg/L; Sigma Chemical Co., St. Louis, MO) and carbenicillin $(75 \mathrm{mg} / \mathrm{L}$; Pfizer Co., New York, NY), and Edwards modified media agar containing $5 \mathrm{mg} / \mathrm{L}$ of colistin sulfate and $2.5 \mathrm{mg} / \mathrm{L}$ of oxolinic acid (Becton Dickinson Microbiology Systems) with $50 \mathrm{~mL} / \mathrm{L}$ of bovine plasma added. Dilutions plated on all media were $1: 10^{2}$ to $1: 10^{6}$. Agar plates were incubated aerobically at $37^{\circ} \mathrm{C}$ for $24 \mathrm{~h}$. Colony-forming units per gram were determined for gram-negative bacteria (total growth on MacConkey agar), coliforms (lactose-positive colonies on MacConkey agar), Klebsiella spp. (pink to red colonies on MacConkey-inositol-carbenicillin agar), and streptococci (total growth on modified Edwards agar). Counts were expressed as the logarithm of colony-forming units per gram of bedding DM. Bacterial counts and moisture content were analyzed by least squares ANOVA using the mixed procedure of SAS (SAS Institute, 2003). The main effects for each variable were treatment, pair, sample day, and week of period. Main effects and possible 2-way interactions were tested. Significance was defined as $P<0.05$.

Mean total gram-negative bacterial (Figure 1A) counts did not differ $(P>0.05)$ between bedding samples taken from daily replacement stalls and those samples from deep-pack stalls across the entire trial $(P>0.05)$. Coliform (Figure 1B) and Klebsiella spp. (Figure 1C) counts were reduced $(P<0.05)$ in recycled manure solids bedding from daily replacement stalls compared with deep-pack stalls on each of d $0,1,2$, and 6. Streptococcal counts (Figure 1D) also differed between treatment groups within each sample day. Streptococcal counts were reduced in bedding from daily replacement stalls compared with deep-pack stalls on d $0(P<0.05)$. In contrast, streptococcal counts were greater $(P<0.05)$ in bedding samples from daily replacement stalls compared with deep-pack stalls on $\mathrm{d}$ 1,2 , and 6 . Dry matter percentage (Figure 1E) of recycled manure solids bedding in daily placement stalls was reduced $(P<0.05)$ on d 0 , did not differ $(P>$ $0.05)$ on $\mathrm{d} 1$ and 2 , and was enhanced on d $6(P<0.05)$ compared with DM percentage in deep-pack stalls.

Several approaches have been reported to decrease bacterial populations in recycled manure during the preparation of bedding before use (Gooch et al., 2006; Husfeldt et al., 2012). However, regardless of procedures used to prepare bedding, mastitis pathogen populations were similar in recycled manure bedding after use in stalls (Gooch et al., 2006; Husfeldt et al., 2012). An emphasis on managing bedding after it is placed into stalls appears to have a greater effect on bacterial populations compared with preparatory measures dur- 

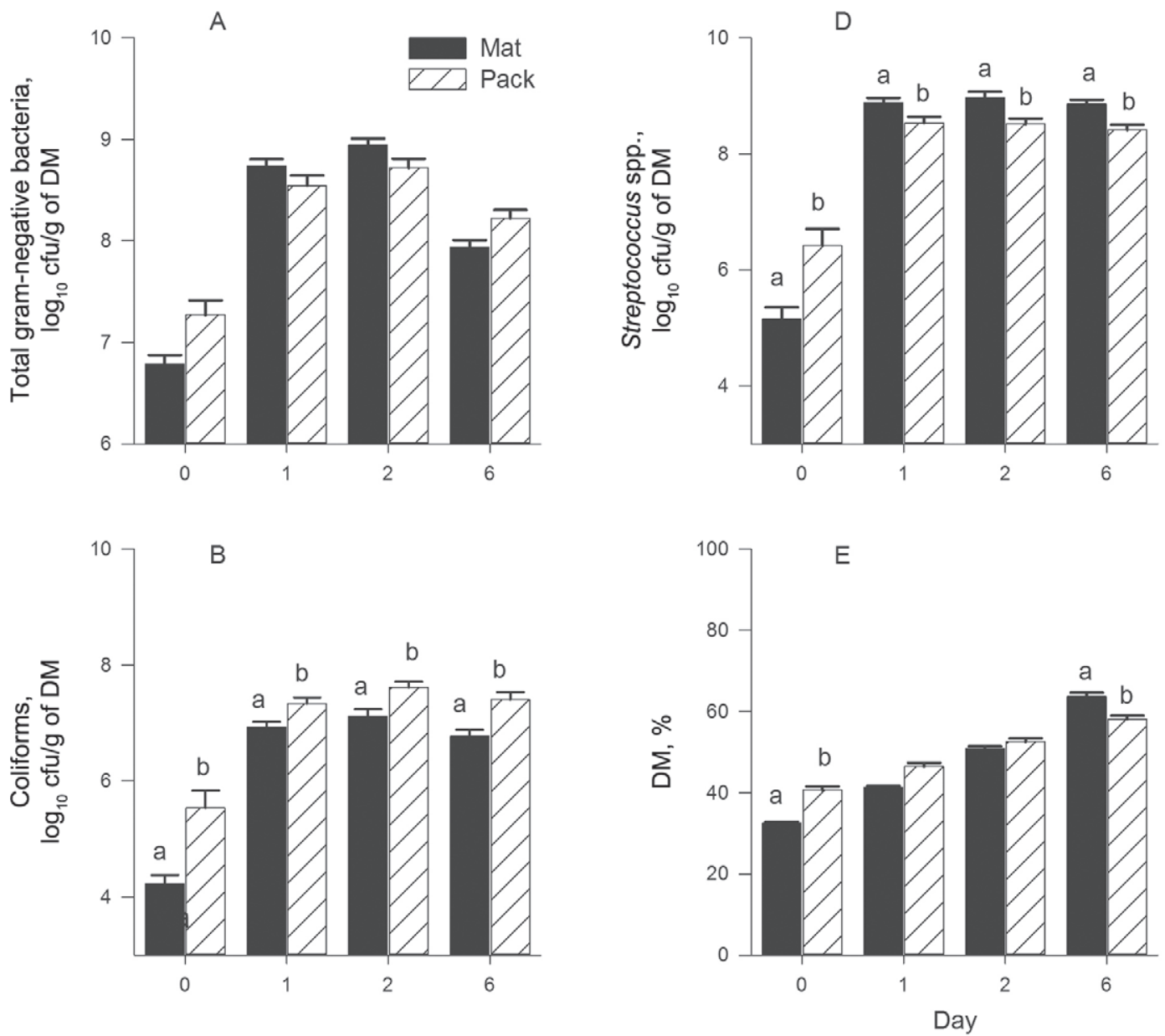

C

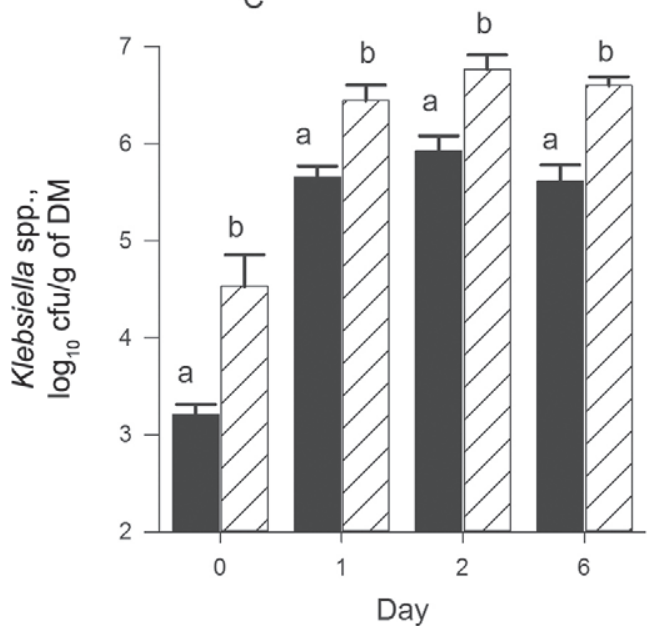

Figure 1. Counts of (A) total gram-negative bacteria, (B) coliforms, (C) Klebsiella spp., and (D) Streptococcus spp., and (E) amount of DM in recycled manure solids bedding either replaced daily or deep packed on d 0,1,2, and 6 after use in freestalls. Error bars represent SE. Means within day with differing letters (a and $\mathrm{b})$ differ $(P<0.05)$.

ing the reclaiming of solids from manure. Results of the current trial agree with the findings of Bramley (1985), who reported that the daily replacement of organic bedding in the rear of stalls decreased the exposure of cows' teats to coliform bacteria. Samples taken from daily replacement stalls in the current trial had lower 
coliform counts compared with deep-pack stalls. This reduction was specifically seen in Klebsiella spp., which was reduced approximately 10-fold each day in daily replacement stalls. A primary source of Klebsiella spp. to contaminate bedding is manure in alleys carried into stalls on hooves and legs as cows enter or stand in stalls before laying down (Zadoks et al., 2011). This source of contamination was consistent between treatments in the current trial as cows were in a single pen and shared the same alleys. Therefore, the daily replacement of recycled manure bedding on mattresses appeared advantageous in controlling exposure to Klebsiella spp. compared with deep-packed recycled manure under comparable, controlled housing conditions.

Streptococcal counts were not controlled by daily replacement of recycled manure bedding from stalls. Streptococcal counts increased greater than 100-fold the first day after bedding was placed in stalls and remained relatively constant for the remainder of the week in both treatment groups. Although the counts were numerically similar each day, streptococcal counts in deep-pack manure bedding were significantly reduced compared with daily replacement on $\mathrm{d} 1,2$, and 6 . The reason for the discrepancy between treatment effects on coliform counts compared with streptococcal counts is unknown, but consistent with the findings of Husfeldt et al. (2012) in an observational study.

The adaptability of bacteria to replicate in bedding is a function of multiple metabolic characteristics of the bacteria coupled with physical and chemical characteristics of the material (Godden et al., 2008). The only physical characteristic of bedding compared in the current study was DM. The DM content was similar between bedding treatments and increased during the week, with fans constantly moving air above stalls throughout the trial. A potential explanation for differing effects of management practices on different pathogens is the initial counts of bacterial groups in recycled manure before use as bedding. Klebsiella spp. counts in recycled manure were near the lower detection limit of the assay before use as bedding, thus implying contamination from manure or other sources provided the inoculate for growth of these bacteria in bedding. A relatively low inoculum of Klebsiella spp. into fresh manure solids resulted in rapid growth over the next $24 \mathrm{~h}$ (Godden et al., 2008). Daily replacement of unused bedding in the current study appeared to force Klebsiella spp. populations to reestablish daily. In contrast, streptococcal populations in recycled manure before use as bedding were greater than $5.0 \log _{10} / \mathrm{g}$ of bedding. The intrinsic streptococci in unused bedding may have provided metabolically adapted isolates that replenished the population daily comparable to deeppack manure stalls. Nevertheless, daily replacement of recycled manure bedding from the back one-third of stalls appeared to be an effective approach to reducing exposure to coliforms, specifically Klebsiella spp., but not effective in reducing streptococcal counts. Bacterial counts in bedding from both daily replacement and deep-pack stalls were elevated throughout the trial and resulted in considerable risk for exposure to teats and development of IMI.

\section{REFERENCES}

Bramley, A. J. 1985. The control of coliform mastitis. Pages 4-17 in Proc. Annu. Meet. Natl. Mastitis Counc., Las Vegas, NV. National Mastitis Council Inc., Verona, WI.

Godden, S., R. Bey, K. Lorch, R. Farnsworth, and P. Rapnicki. 2008. Ability of organic and inorganic bedding materials to promote growth of environmental bacteria. J. Dairy Sci. 91:151-159.

Gooch, C. A., J. S. Hogan, N. Glazier, and R. Noble. 2006. Use of post-digested separated manure solids as freestall bedding: A case study. Pages 151-160 in Proc. Annu. Meet. Natl. Mastitis Counc., Tampa, FL. National Mastitis Council Inc., Verona, WI.

Hogan, J., and K. L. Smith. 2012. Managing environmental mastitis. Vet. Clin. North Am. Food Anim. Pract. 28:217-224.

Hogan, J. S., K. L. Smith, K. H. Hoblet, D. A. Todhunter, P. S. Schoenberger, W. D. Hueston, D. E. Pritchard, G. L. Bowman, L. E. Heider, and B. L. Brockett. 1989. Bacterial counts in bedding materials used on nine commercial dairies. J. Dairy Sci. $72: 250-258$.

Husfeldt, A. W., and M. I. Endres. 2012. Association between stall surface and some animal welfare measurements in freestall dairy herds using recycled manure solids for bedding. J. Dairy Sci. 95:5626-5634.

Husfeldt, A. W., M. I. Endres, J. A. Salfer, and K. A. Janni. 2012. Management and characteristics of recycled manure solids used for bedding in Midwest freestall dairy herds. J. Dairy Sci. 95:21952203.

SAS Institute. 2003. SAS User's Guide: Statistics. Version 9 ed. SAS Inst. Inc., Cary, NC.

Zadoks, R. N., H. M. Griffiths, M. A. Munoz, C. Ahlstrom, G. J. Bennett, E. Thomas, and Y. H. Schukken. 2011. Sources of Klebsiella and Raoultella species on dairy farms: Be careful where you walk. J. Dairy Sci. 94:1045-1051.

Zdanowicz, M., J. A. Shelford, C. B. Tucker, D. M. Weary, and M. A. G. Von Keyserlingk. 2004. Bacterial populations on teat ends of dairy cows housed in free stalls and bedded with either sand or sawdust. J. Dairy Sci. 87:1694-1701. 